\title{
A case study of rooftop rainwater harvesting of Renavi village in Sangli District of Western Maharashtra: New approach of watershed development in India
}

\author{
Pawar C. B. ${ }^{{ }^{*}}$, Patil S. S. ${ }^{2}$ and Pawar R. P. ${ }^{3}$ \\ ${ }^{1}$ Department of Environmental Studies, Sangola College, Sangola District, Solapur, (MH) 413007, India. \\ ${ }^{2}$ Department of Environmental Sciences, Dr. Babasaheb Ambedkar Marathwada University, Aurangabad \\ $431004(\mathrm{MH})$, India. \\ ${ }^{3}$ WMC, YASHADA, Pune, 411033(MH), India.
}

Received 5 January, 2011; Accepted 10 June, 2014

\begin{abstract}
The population in India is expected to stabilize around 1640 million by the year 2050, as a result, gross per capita water availability will decline from $1820 \mathrm{~m}^{3} / \mathrm{year}$ in 2001 to as low as $\sim 1140 \mathrm{~m}^{3} / \mathrm{year}$ in 2050 . Thus, the growing concern about water scarcity challenges us to think of alternative solutions to avoid the current problem of water scarcity. The micro-watershed development, which ensures availability of water for agriculture and domestic purpose and the roof-top rain water harvesting measures, which provide water for domestic consumption are often suggested as solutions for overcoming water shortage in drought prone areas of India. This article presents the success story of rooftop rain water harvesting program in Renavi village in Sangli District of Maharashtra, India. The potential assessment of the village revealed that, approximately 20 lakh liters of water collected from rooftops, will satisfy the demand of a population of $\mathbf{1 3 0 0}$ for at least $\mathbf{7 8}$ days. This estimation is as per the United Nations standard, which prescribes the requirement of 20 liters of water (cooking and domestic uses) per person per day in India.
\end{abstract}

Key words: Roof top, rain water harvesting, water scarcity.

\section{INTRODUCTION}

A leaf stretched out from its branch, catches a drop of rain, channeling water towards the ground as its base, for millions of years; this simple rain collection technique has fueled life in many reaches of this planet (Neuman et al., 2007). Accordingly, roof-top rain water harvesting techniques are most simple, but neglected in the water harvesting programs. It requires two basic elements: a catchment, which is a broad surface to catch the rain and method or device for storing the captured rain (Thomas, and John, 1985). Roof top rain water harvesting has become inevitable as fresh and good quality water necessary for human consumption, social, economic and cultural needs and for environmental requirement is rapidly becoming scarcer.

In the 1950's only a handful of countries faced water shortages. In the nineties, the numbers of countries

*Corresponding author. E-mail:pawarc b16@gmail.com, Tel/Fax:-020-2560800.

Author(s) agree that this article remain permanently open access under the terms of the Creative Commons Attribution License 4.0 Intemational License 
facing the water deficit has grown to 26 with the populations of 300 million (Abu-zeid, 1998). The population of India is expected to stabilize around 1640 million by the year 2050, as a result, gross per capita water available will decline from $\sim 1140 \mathrm{~m}^{3} / y e a r$ in 2050 . Total water requirement of the country for various activities around the year 2050 has been assessed to be $1450 \mathrm{~m}^{3} / y e a r$. This is significantly more than the current estimate of utilizable water resources potential (1122 $\mathrm{m}^{3} /$ year) through conventional development strategies (Gupta and Deshpande, 2004).

In a bid to conserve rain water and recharge groundwater for drought proofing, the Indian government has mounted the watershed approach to rainwater harvesting and conservation in a big way. Over US\$ 3.5 billion are being spent by the government, bi- and multi lateral agencies. However, droughts have kept pace with the investment increasing in frequency (Sharma, 2001). Rooftop rainwater harvesting is one of the optimistic and economically viable methods of rainwater harvesting. Rooftop rainwater is allowed to percolate in the ground and become helpful to increase ground water recharging groundwater aquifers.

In the case of India, it was found that the success stories of watershed program happen in villages where people's participation remains active. Peoples participation in socio-environmental issues remains key to community centered development, and has remained largely stuck in the 'you participate in my program mode' (Sharma, 2001). In this context, the people centered rooftop rain water harvesting movement play an important role in conservation of water resources in Renavi village of Khanapur block of Sangli District, Maharashtra, the village came into limelight during our study visit. The present study was conducted with the objectives below:

(1) To study rain water harvesting potential of Renavi village

(2) To understand the participatory approach of collective action of people in rooftop rainwater harvesting

(3) To provide remedies for sustainable benefits of rain water harvesting models.

\section{METHODOLOGY}

A general village survey was carried out to assess the rooftop area of houses; number of houses were collected through personal discussion with beneficiaries and Grampanchayat* records. The information related to the geographical location of Sangli district and monsoon collected from socio- economic review of Sangli District respectively. For the sake of reliability, the quantitative data was collected from a focus group discussion.

\section{Background of study}

The Sangli district is located around latitude $16^{\circ} 51^{\prime} 6^{\prime \prime} \mathrm{N}$ and $74^{\circ}$ 33' 36" E longitude. This region falls in the semi arid tract of Deccan plateau (Sankpal, 2003). The district comprising the Tasgaon,
Kavathemahankal, Atpadi, Khanapur and Kadegaon block is grouped under the drought prone regions. In the early parts of 2001 - 2003 the ground water level dropped in an alarming rate in 494 villages out of 730 villages (67.67\%) (Jalja, 2005). In same period, watershed development projects were carried out in the 100 villages, where peoples' participation play important role. During recent decades the planners the government, stake holders and donor agencies have perceived that the goal of social development cannot be achieved unless the beneficiaries participate in the entire process of preparation, implementation and follow up on the development of plans and programs (Robert, 1994). The people's participation remains considerably high (Table 1 and Figure 1).

\section{Funding of rainwater harvesting program in Renavi village of Sangli District}

Rainwater harvesting is a method raised as the optimistic and economically viable method of water harvesting became compulsory for buildings, apartments and entertainment centers etc. having rooftop area of $>1000 \mathrm{~m}^{2}$ for urban areas. The rural area of India and other nations also having wide chances to collect rainwater from the rooftops with low investment like the present case. The funding distribution is given in Table 3.

A total of Rs. 6, 04,000 was invested as contribution by Government agencies and villagers (Table 3). The capital cost for harvesting roof and surface water structures in Delhi is estimated at Rs. 2.5 crore per 4 million liters per day ( $\mathrm{mlpd}$ ) as compare to the average cost of Rs. 4 crore mlpd for water obtained from Himalaya reservoirs and Rs. 3 crore mlpd water received through canals (Bannerjee et al., 2001). This example simply proves that this technique is feasible in both assured as well as drought prone areas. The statistics of the tank construction as per water demand of family and economic viability is given in Table 4.

It is noted that as the construction cost of the $5000 \mathrm{~L}$ tank is only Rs.11, 700 (260 US Dollars) these costs are reduced with increasing capacity of the tank. The Government of Maharashtra granted limited finance to this activity. For the sustainability of the Rain Water Harvesting projects, the following components are essential for storage of the harvested water.

\section{Rainfall data collection}

Rainfall data was collected from the Jalja Report. The Renavi village is situated in the Khanapur block in the eastern part of Sangli District, whose annual rainfall is $558 \mathrm{~mm}$ (Jalja, 2005). For the present research, the annual rainfall of the year 2005 which was $527 \mathrm{~mm}$ have been considered for carrying out potential assessment.

\section{Coefficient of runoff}

Coefficient of Runoff $(\mathrm{Cr})$ for any catchments is defined as "The ratios between volumes of water that runs off and that of total volume of rain that fall on the surface" (Gould and Nissen, 1999). The runoff coefficients for the different structures are given in Table 2. In the village survey, a maximum number of houses had Chawl (the perfectly finished sheets of soil) System. Taken into account the rooftops, the 0.8 Runoff Coefficient is taken as a standard for the present research.

$$
\mathrm{Cr}=\frac{\text { Volume of runoff water }}{\text { Volume of rain water that fall on the surface }}
$$

The run off coefficient of Renavi village has been taken as 0.8 
Table 1. Block-wise rainfall data $(\mathrm{mm})$ of drought prone areas of Sangli District 2000-2006.

\begin{tabular}{lc}
\hline Block & Average annual rainfall (mm) \\
\hline Miraj & 487 \\
Kavate-Mahankal & 493 \\
Tasgaon & 461 \\
Jat & 415 \\
Khanapur & 558 \\
Atapadi & 237 \\
Kadegaon & 545 \\
District & 459 \\
\hline
\end{tabular}

(Source: Jalja- Report on Sangli District Watershed Program, 20002006) (Jalja and Sangali, 2008).

Table 2. Coefficient of runoff.

\begin{tabular}{lcc}
\hline S/N & Type of roof top & Runoff coefficient \\
\hline 01 & Galvanized Sheets & 0.9 \\
02 & Asbestos & 0.8 \\
03 & Cement concrete & 0.7 \\
04 & Grass & 0.0 \\
\hline
\end{tabular}

*Source-Government Resolution No./Govt. of Maharashtra VIDE LT. CHE/PP/36.

Table 3. Funding of Rainwater harvesting project in Renavi Village.

\begin{tabular}{lccc}
\hline S/N & Government funding & Villagers funding & Total cost of the project \\
\hline 1 & Rs. $5,30,000$ & Rs. 74,000 & Rs. $6,04,000$ \\
\hline
\end{tabular}

(Source: Grampanchayat Records: 2004)

which is taken as standard for the designing of pucca (well built up) rooftop catchments system.

\section{Potential of rain water supply}

Potential is calculated by using the formula given below (Gould and Nissen, 1999):

\section{$\mathrm{P}=\mathrm{R} \times \mathrm{A} \times \mathrm{Cr}$}

Where $R=$ mean annual rainfall in meter, $A=$ catchment area in $\mathrm{m}^{2}$, $\mathrm{Cr}=$ coefficients of runoff.

\section{RESULTS AND DISCUSSION}

\section{Rain water harvesting at Renavi Village}

The annual rainfall of the year 2005 of Khanapur block which is $557 \mathrm{~mm}$ is considered for the research work. The village survey revealed that the Renavi village has 231 houses and total population is 1300 . Of the total houses 108 houses (46.98\%) having traditional rooftops, not suitable for collecting rain water. A total of 123 houses had suitable rooftops to collect water, out of which 70 houses were selected for rainwater harvesting program. While 53 more houses having suitable rooftop were used to harness the rainwater, but not included in the program (Table 5).

At present the water harvested from rooftops of the seventy houses, which is estimated to be $11,63,616 \mathrm{~L}$ is used for recharging the 17 bore-wells and 4 dug-wells located near the housing area. It is proposed that if collected water is stored in the tank, then it will help to fulfill the drinking and cooking water related needs of most of the entire population of 1300 persons, for at least 45 days. This estimation is as per United Nations standards, which prescribes the requirement of $20 \mathrm{~L}$ of water per person per day. It is also proposed to provide the water harvesting structures to additional 153 houses, which provide to additional 53 houses, which would enable collection of additional $8,55,848 \mathrm{~L}$ of water, which will in turn fulfill the above said need of the entire 
Table 4. Budget for Sump/Tank construction.

\begin{tabular}{lcccccc}
\hline Component & $\mathbf{5 0 0 0}$ Lts & $\mathbf{6 0 0 0}$ Lts & $\mathbf{7 0 0 0}$ Lts & $\mathbf{8 0 0 0}$ Lts & $\mathbf{9 0 0 0}$ Lts & $\mathbf{1 0 0 0 0}$ Lts \\
\hline Tank & 7600 & 8090 & 9070 & 9470 & 10380 & 10835 \\
Filter unit & 350 & 350 & 350 & 350 & 350 & 350 \\
Gutter & 3000 & 3000 & 3000 & 3000 & 3000 & 3000 \\
Down and flush pipe & 750 & 750 & 750 & 750 & 750 & 750 \\
Total Cost & 11700 & 12190 & 13170 & 13750 & 14480 & 14935 \\
Cost per Lts* (In Rupees)** & 2.34 & 2.04 & 1.88 & 1.7 & 1.61 & 1.49 \\
\hline
\end{tabular}

*Lts- Liters of water, ${ }^{* *} 1$ US dollar $=45$ Rupees of Indian currency.

Table 5. Rain water harvesting at Renavi Village.

\begin{tabular}{|c|c|c|c|c|c|c|}
\hline $\mathbf{S} / \mathbf{N}$ & $\begin{array}{l}\text { Roof-top surface } \\
\text { area }\left(\mathrm{m}^{2}\right)\end{array}$ & $\begin{array}{l}\text { Average roof-top } \\
\text { surface area }\left(\mathrm{m}^{2}\right)\end{array}$ & $\begin{array}{l}\text { No. of } \\
\text { Houses }\end{array}$ & $\begin{array}{c}\% \text { of } \\
\text { Houses }\end{array}$ & $\begin{array}{c}\text { Estimated Roof-top } \\
\text { area }\left(\mathrm{m}^{2}\right)\end{array}$ & $\begin{array}{c}\text { Estimate of water } \\
\text { harvesting } \\
\text { (Lakh liters) }\end{array}$ \\
\hline \multicolumn{7}{|c|}{ Houses with roof top rainwater harvesting structures. (Annual rainfall $527 \mathrm{~mm}$.) } \\
\hline 1 & $50-70$ & 60 & 4 & 5.71 & 240 & $1,01,184$ \\
\hline 2 & $40-60$ & 50 & 20 & 28.57 & 1000 & $4,21,600$ \\
\hline 3 & $30-50$ & 40 & 23 & 32.85 & 920 & $3,87,872$ \\
\hline 4 & $20-40$ & 30 & 16 & 22.85 & 480 & $2,02,368$ \\
\hline 5 & $10-30$ & 20 & 5 & 7.14 & 100 & 42,160 \\
\hline \multirow[t]{2}{*}{6} & $00-20$ & 10 & 2 & 2.85 & 20 & 8,432 \\
\hline & $00-70$ & 39.42 & 70 & 100 & 2760 & $11,63,616$ \\
\hline \multicolumn{7}{|c|}{ Houses without roof top rainwater harvesting structures. (Annual rainfall $527 \mathrm{~mm}$.) } \\
\hline 1 & $50-70$ & 60 & 8 & 15.09 & 480 & $2,02,368$ \\
\hline 2 & $40-60$ & 50 & 6 & 11.32 & 300 & $1,26,480$ \\
\hline 3 & $30-50$ & 40 & 12 & 22.64 & 480 & $2,90,904$ \\
\hline 4 & $20-40$ & 30 & 23 & 43.39 & 690 & $2,90,904$ \\
\hline \multirow[t]{2}{*}{5} & $10-30$ & 20 & 4 & 7.54 & 80 & 33,728 \\
\hline & $10-70$ & 38.30 & 53 & 100 & 2030 & $8,55,848$ \\
\hline
\end{tabular}

(Based on authors field survey).

population for 33 more days. It was found that water table had risen by $4.15 \mathrm{~m}$ (on average) in the bore-wells which were connected to harvesting structures, and no significant change occurred in the bore-wells which were not connected to the rooftops (Table 6). Thus, rain water harvesting technique is an effective tool for satisfying the demand of domestic water.

\section{Ground water quality assessment from the open well and bore wells in the Renavi village}

Thirteen water samples were collected including 3 water samples from bore-wells which were not connected to the roof-tops. The results were compiled with the WHO and ISI values of drinking water standards. Analysis shows that, the water values for $\mathrm{pH}$ is ranging between 7.6 to 8.6, $\mathrm{pH}$ values found quite safe for drinking of the bore well water. Total Dissolved Solids (TDS) is $301 \mathrm{mg} / \mathrm{L}$ which is within permissible limits of WHO and ISI standards. The parameters such as $\mathrm{Ca}$ (Calcium), Mg (Magnesium), and $\mathrm{Na}$ (Sodium) were found within limits of WHO standards (Table 7). The slightly alkaline $\mathrm{pH}$ value 8.6 is recorded for the one sample which is not connected to the rooftop structure. The TDS value is recorded at $1213 \mathrm{mg} / \mathrm{L}$, which is slightly on a higher side but within permissible limits of the ISI standards. Overall results of the physico-chemical analysis show that the quality of bore-wells is very soft and within the limits of WHO and ISI standards. In the context of the heavy contamination of surface and sub-surface fresh water reservoirs, the present case is very important. The brief analysis is given in the Tables 7 and 8.

\section{DISCUSSION}

Roof top rain water harvesting measures need to be 
Table 6. "t" value for ground water table recorded in the year 2004.

\begin{tabular}{|c|c|c|c|c|}
\hline $\begin{array}{l}\text { Water table in Bore } \\
\text { wells }\end{array}$ & $\begin{array}{c}\text { Total Bore wells } \\
\text { undertaken to } \\
\text { study }\end{array}$ & $\begin{array}{c}\text { Before commissioning } \\
\text { rain water harvesting } \\
\text { system } \mathrm{A}\end{array}$ & $\begin{array}{c}\text { After commissioning } \\
\text { rain water harvesting } \\
\text { system B }\end{array}$ & $\begin{array}{c}\text { Difference in water } \\
\text { Table A-B }\end{array}$ \\
\hline $\begin{array}{l}\text { Houses with rain water } \\
\text { harvesting models }\end{array}$ & 17 & $17.24 \mathrm{~m}$ & $13.09 \mathrm{~m}$ & $4.15 \mathrm{~m}$ \\
\hline $\begin{array}{l}\text { Houses without rain } \\
\text { water harvesting models }\end{array}$ & 13 & $16.96 \mathrm{~m}$ & $16.07 \mathrm{~m}$ & $0.89 \mathrm{~m}$ \\
\hline
\end{tabular}

(Based on authors field survey.)

Table 7. Physico-chemical analysis of selected parameters.

\begin{tabular}{|c|c|c|c|c|c|c|c|c|c|}
\hline$S / N$ & $1 \mathrm{pH}$ & $\begin{array}{c}\text { 2.EC } \\
\text { (umohs) }\end{array}$ & $\begin{array}{l}\text { 3.TDS } \\
\text { (mg/L) }\end{array}$ & $\begin{array}{c}\text { 4.T/HAR } \\
(\mathrm{mg} / \mathrm{L})\end{array}$ & $\begin{array}{c}\text { 5.T/ALK } \\
\text { (mg/L) }\end{array}$ & $\begin{array}{c}\text { 6.Ca } \\
(\mathrm{mg} / \mathrm{L})\end{array}$ & $\begin{array}{c}\text { 7.Mg } \\
\text { (mg/L) }\end{array}$ & $\begin{array}{c}\text { 8.Na } \\
(\mathrm{mg} / \mathrm{L})\end{array}$ & $\begin{array}{c}9 . \mathrm{K} \\
(\mathrm{mg} / \mathrm{L})\end{array}$ \\
\hline 1 & 8.3 & 470 & 301 & 116 & 124 & 35.2 & 6.804 & 50 & 1 \\
\hline 2 & 8.5 & 487 & 312 & 172 & 200 & 27.2 & 25.272 & 29 & 0.5 \\
\hline 3 & 7.6 & 623 & 399 & 248 & 144 & 27.2 & 43.74 & 26 & 1.1 \\
\hline 4 & 7.9 & 868 & 556 & 300 & 168 & 54.4 & 39.852 & 55 & 0.4 \\
\hline 5 & 8.6 & 567 & 768 & $972^{*}$ & 176 & $329.6^{\star}$ & $101^{*}$ & 43 & $0.6^{*}$ \\
\hline 6 & 8.2 & 783 & 499 & $800 *$ & 144 & $157^{\star}$ & $121.5^{\star}$ & $194^{\star}$ & $0.8^{*}$ \\
\hline 7 & 8.3 & 748 & 479 & 270 & 168 & 28.8 & 48.114 & 32 & 0.5 \\
\hline 8 & 8.2 & 1838 & 1213 & $692^{*}$ & 184 & $249.6^{\star}$ & 16.524 & 65 & 0.7 \\
\hline 9 & 8 & 212 & 657 & 344 & 204 & 64 & 44.712 & 52 & 6 \\
\hline 10 & 8.3 & 801 & 513 & 220 & 360 & 11.2 & 46.656 & 136 & 0.5 \\
\hline 11 & 8.4 & 755 & 483 & 240 & 200 & 41.6 & 33.048 & 71 & 0.9 \\
\hline 12 & 8.2 & 530 & 339 & 152 & 168 & 33.6 & 16.524 & 44 & 0.3 \\
\hline 13 & 8.4 & 467 & 391 & 308 & 132 & 75.2 & 29.16 & 99 & 2.2 \\
\hline
\end{tabular}

* The water samples collected from the bore-wells not connected to rooftops. Kranti Co-operative Sugar Mill, Soil and Water analysis Laboratory Report, 2010.

Table 8. Ground water quality assessment between of Rooftop connected and not connected bore wells with WHO and ISI standards.

\begin{tabular}{lcccccc}
\hline \multirow{2}{*}{ Parameter } & \multicolumn{2}{c}{ WHO standards } & \multicolumn{2}{c}{ ISI Standards } & \multicolumn{2}{c}{ Observed Values } \\
\cline { 2 - 7 } & P & E & P & E & Minimum & Maximum \\
\hline $\mathrm{pH}$ & 7 & 8.5 & 7 & 8.5 & 7.6 & $8.6^{\star}$ \\
$\mathrm{EC}$ & - & - & - & - & 212 & $1838^{\star}$ \\
TDS & - & - & 500 & 2000 & 301 & 755 \\
T/HAR & - & - & 300 & 600 & 116 & $972^{\star}$ \\
T/ALK & 75 & 200 & 200 & 600 & 132 & 360 \\
$\mathrm{Ca}$ & 50 & 150 & 75 & 200 & 11.2 & $329.6^{\star}$ \\
$\mathrm{Mg}$ & 200 & - & 30 & 100 & 6.8 & $121^{\star}$ \\
$\mathrm{Na}$ & - & - & 150 & - & 26 & $194^{\star}$ \\
$\mathrm{K}$ & - & - & - & - & 0.3 & 2.2 \\
\hline
\end{tabular}

P- Permissible Limits, E-Excessive Limits. ${ }^{*}$ The higher values recorded from the water sample which was not connected to rooftops.

given priority in the drought prone areas and should be incorporated in the watershed development programs. As illustrated by this case, roof top rain water harvesting measures helps in fulfilling the domestic water need as well improving the ground water level by few meters. On the other hand, in some states of India such as Andhra 

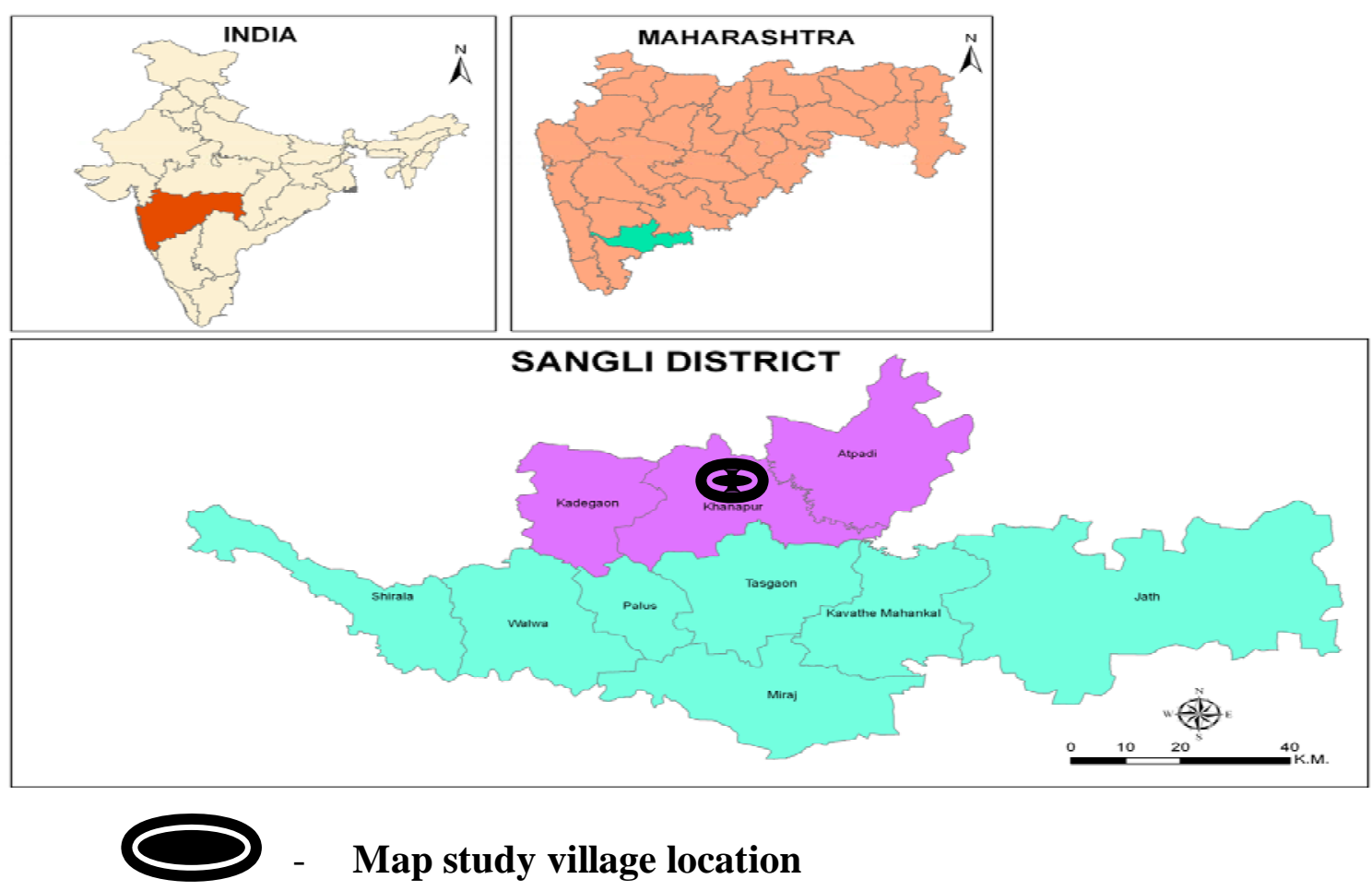

Figure 1. Map of study village location.

Pradesh, Madhya Pradesh, Gujrat and Rajashthan the level of fluoride in ground water is above the permissible limit $(1.5 \mathrm{mg} / \mathrm{L})$. In parts of the West Bengal of India and Bangladesh, the ground water also contains arsenic above the permissible limit of 50 micrograms / liter. In these situations also, roof water harvesting is desirable although there may be no shortage in groundwater. Rainwater is practically free of dissolved solids as well as arsenic and fluorides (report on rain water supply) (Athavale, 2003). Rain water harvesting techniques have the potential of reducing water scarcity. Technically, it is possible to drought proof the entire India, even if half of the average annual rainfall of $1170 \mathrm{~mm}$ is captured on 1.12 ha of land in each of the country's 5, 87,226 villages, then 6.57 million liters of rain water will be collected in each village, which can meet the annual cooking and drinking needs of a population of 1200 (The Ecological Foundation, 2003).

It is argued that due to consideration of gestation period and capital requirement, rainwater harvesting and water conservation measures must receive the highest priority followed by renovation and recycling to be followed by intra and then inter basin transfers in the last phase (Gupta and Deshpande, 2004). Across the globe, rainwater harvesting techniques are reappearing in a variety of individual, community and government projects .The government of Maharashtra VIDE LT. CHE/PP/36 dated 0.2002 has made compulsory for buildings, having area $>1000$ sq.km, to provide rainwater harvesting arrangements. Such provision plays vital roles in natural resource conservation. These types of models are highly practicable throughout countries where the region is faced with similar climatic conditions.

\section{Conflict of Interests}

The authors have not declared any conflict of interests.

\section{REFERENCES}

Athavale RN (2003). Water harvesting and sustainable supply in India. Rawat Publications, Jaipur India. P. 48.

Abu -zeid MA (1998). water and sustainable development : The vision for world water, life, and the environment, ELSEVIER, water policy pp. 9-19.

Neuman, Janet C, Troy $P$ (2007). Remembering rain, Levis and clark law shool, 37 envtl. L, P. 2.

Thomas S, John L (1985). water harvesting, complied in united nations Food and AGRIC.ORG(FAO), The role of forestry in combating desertification, FAO DOC P. 115/E.

Gupta SK, Deshpande RD (2004). Water for Indian 2050: First order assessment of available option, Current science 86(9):1216-1223.

Sharma S (2001). Where every drop of rain contents: A case study on natural resources regeneration and management in Sargunja district of Chattisgarh.

The Ecological Foundation (2003). New Delhi. Sharma S: Report on Rooftop rainwater Harvesting:- Water harvesting and sustainable supply in India. P. 48.

Jalja (2005). A report on watershed development program in Sangali district, pp. 5-9. 
Jalja, Sangali (2008). District Meteorological Department: Rain fall data 2005-2006.

Gould, Nissen (1999). Rainwater catchments system for domestic supply International Technology Publication, Londan.

Sankpal SS (2003). A political review of Tembhu and Mahisal cooperatives lift irrigation, M.Phil Thesis submitted to the Shivaji University, Kolhapur. pp. 1-5.
Robert C (1994). The origin and practice of partipartory rural appraisal world development 22(7).

Kranti Co-operative Sugar Mill, Soil and Water analysis Laboratory Report (2010). 